\title{
Ni formas ni signos. El destino moderno de la imagen-fantasma
}

\author{
Luis Puelles Romero \\ Universidad de Málaga \\ Ipr@uma.es
}

RESUMEN: Desde ciertos presupuestos exploratorios del «arte moderno" como destino de emergencia de la imagen-fantasma (a partir de la lectura del Sofista por Deleuze), se ensaya en estas páginas la posibilidad de que la soberanía de la imagen moderna no radique predominantemente en sus valores formales y de pureza, sino en su potencia de resistencia al entendimiento. Kant, Baudelaire y Lautréamont, en lo relativo a la definición de la imagen irreductible a percepción «realista», o Ingres, el último Goya y un Manet más enigmático que meramente plasticista, nos orientan hacia aspectos (la querella de las imágenes contra los signos, las nociones de figura y extrañamiento) y autores (Redon, Picabia, entre otros) menos atendidos por la historiografía de las conquistas formales y «autonomistas».

PALABRAS CLAVE: Figura; Signo; Imaginación; Extrañamiento; Arte Moderno.

\section{Neither Forms nor Signs. The Modern Destiny of the Ghost Image}

ABSTRACT: Taking certain exploratory assumptions of «modern art» as a starting point for an emergency destiny of the ghost image (from the reading of the Sophist by Deleuze), the possibility is examined in these page of the sovereignty of the modern image not residing predominantly in its formal values and purity, but in its power of resistance to understanding. Kant, Baudelaire and Lautréamont, regarding the definition of the irreducible image to «realistic» perception, or Ingres, or the last Goya and a more enigmatic than merely plastic Manet, guide us towards aspects (the dispute over images versus signs, the notions of figure and estrangement) and authors (Redon, Picabia, among others) less heeded by the historiography of the «autonomists» and formal conquests.

KEYWORDS: Figure; Sign; Imagination; Estrangement; Modern Art.

Recibido: 4 de febrero de 2018 / Aceptado: 2 de mayo de 2018.

«Crear una figura sin modelo de ninguna clase, eso es arte".

Francis Picabia

El relato de las conquistas formales que sirvió a Alfred Barr para dotar de un sentido progresivo al cúmulo de obras europeas que constituían el fondo inicial del MoMA recibió hacia la mitad del siglo la «validación» teórica aportada por autores como Hans Sedlmayr y Clement Greenberg. Sedlmayr reconoció en las muestras mayores de lo que comenzaba a definirse como «arte moderno» la propiedad esencial y diferenciadora de constituirse en los términos de «ser totalmente 'puro'». Tal pureza, comprendida como categoría ontológica, y de la que este autor dice que podría también significarse con las nociones de autonomía o autarquía, habrá de cumplirse de forma «absoluta» (esto es, libre de toda causalidad que no sea la de la propia autogénesis de la obra) y desprendida de cualquier vínculo o hibridación con cuanto perteneciera a los medios y posibilidades de las demás artes, por lo que la exigencia de pureza debería entenderse como no siendo en nada lo que no se es

Cómo citar este artículo: PUELLES ROMERO, Luis, «Ni formas ni signos. El destino moderno de la imagen-fantasma», Boletín de Arte-UMA, n. 39 , Departamento de Historia del Arte, Universidad de Málaga, 2018, pp. 195-204, ISSN: 0211-8483, DOI: http://dx.doi.org/10.24310/BoLArte.2018.v0i39.4123 
sustancialmente. Así constata Sedlmayr el advenimiento de esta «purificación» autonomista:

Al igual que sucedió con la arquitectura, también la pintura, a través de una múltiple sucesión de acontecimientos enormemente estratificados y ramificados, que tiene lugar en el siglo XVIII, ha eliminado paulatinamente todos los elementos «heterónomos", a fin de llegar a ser autónoma en su totalidad. Cuando este proceso se aproxima a sus fronteras naturales surge la pintura «pura», «absoluta». Esto sucedió hacia 1910. Entonces aparecieron, con Picasso, Kandinsky, Malevitsch [sic] y otros, las primeras pinturas «puras» (Sedlmayr, 1990: 27).

Por su parte, el influyente Clement Greenberg ha concedido a la "planitud ineluctable de la superficie del cuadro» el privilegio de que sea en ella donde se libra el combate de la pintura por el que la forma gana para sí la soberanía plástica que la hace moderna. "Y ello porque sólo la planitud era una cualidad única y exclusiva del arte pictórico» (Greenberg, 2006: 113). Muy poco después de que lo hiciera Sedlmayr, también Greenberg encuentra en la «pureza» el valor que permitiera a la pintura obtener la capacidad emancipatoria por la que definirse y proyectarse a sí misma.

Ambos autores sostienen su noción de pureza, y con ella la de autonomía, en la tarea de que la pintura sepa explorar y llevar a sus mayores logros cuanto pertenece de forma intrínseca a sus propios medios. Efectivamente, enseguida advertimos que esta propuesta -sobre las que se erigirán paulatinamente las poéticas de la Abstracción, ya desde el paisajismo romántico- tiene un umbral histórico bien preciso: el Laocoonte de Lessing (1766), el cual, si bien no es el primer documento en el que se establecen parangones entre las artes (práctica que es casi un género en el Renacimiento: basta leer a Durero, Leonardo o Cennini), no es menos cierto que nunca antes se insistió tanto en la diferenciación entre los «medios» y, sobre todo, en cómo cada medio -espacial o temporal- determina las posibilidades expresivas inherentes a cada arte. Y, todavía en el siglo XVIII, el proceso de estetización que alcanza a Kant nos ilustra acerca de toda una genealogía -e ideología- de la «autonomía formal» que el propio Greenberg ha convertido en lineal y hasta teleológica. Así, se estaría tentado a pensar que hay una historia de la pintura que, recibiendo de Kant los honores para su emancipación «formalista», llegaría siquiera a Pollock, y que pudiera hacer de éste el ejemplo culminante de la belleza libre kantiana, cuando la forma queda libre tanto de significar como de tener que existir más allá de la presencia plástica que es.

Cabría decir que este «vector» de la modernidad, el de la estetización y los formalismos -prácticos y metodológicos, poieticos y hermenéuticos-, el de la plasticismos y sus conquistas imparables, el de las autorreferencialidades y autonomías, el de las purezas y los alejamientos seculares de la mímesis y la semántica, este vector, de tanta impronta en la pedagogía museística, se afirma mediante la elusión de otro vector moderno, acaso menos atendido por el discurso historiográfico legitimante, quizá menos cómodo para las disposiciones y didácticas operadas por la institución museística. Este otro vector tiene también su "génesis" en Kant, y, por cierto, también fue explorado por Manet. Pero sin tomar de ellos lo mismo; ni la forma sin semanticidad ni la plasticidad sin significación. Y sí observando, en cambio, cuanto aporta Kant a la teoría moderna de la imaginación y cuanto cabe situar en las pinturas de Manet cierto origen desde el que trazar la destitución y parodia de la significación (y no, insisto, ese otro origen, bien reconocido, que sería -desde Zola hasta Bataille- el de la pintura pura y silenciosa en la que nada se significa).

Enseguida retomaremos a Kant, para detenernos en su teoría de la imaginación, pero antes desearía precisar un poco más lo que nos ocupará en las próximas páginas. Lo que trato de proponer es que, de forma paralela a una modernidad radicada en los valores de pureza y autonomía, hay otro linaje de lo moderno que toma sus fuerzas de la capacidad que se da para sí la pintura -a partir del Goya más personal y subjetivo, el Manet más equívoco y menos "superficialista», Odilon Redon y también Seurat, algo después Picabia...- para permanecer irreductible a la lógica de la significación, a las hermenéuticas que persiguen su inteligibilidad. De este modo, junto al linaje, suficientemente teorizado (es más: su teorización es la condición de su secuencialidad), de la forma pura, sería adecuado darnos los medios para la comprensión de ciertas obras -no hilvanadas en una tradición ya fijada- que, digámoslo así, «suceden» en las afueras del vector hegemónico.

Ambos dominios modernos de la creación pictórica (acaso en algunos aspectos también fotográfica), el de la pureza de las formas y el de las figuras irreductibles ${ }^{1}$, comparten la condición soberanista de mantenerse resistentes a 
la significación. Hasta el punto de que bien podríamos convenir que fuera esta «potencia de resistencia» a dilucidación inteligible, a explicación disolvente de la singularidad impensable, a significación que acabe con la presencia misma de la picturalidad, la que dota a las obras visuales modernas de su carácter más propio. Aún más: podría suponerse que esta potencia no es obtenida de una vez para siempre, sino que es justamente manteniéndose en tensión de sustracción respecto de la lógica de la identificación, en una tensión que, por lo mismo, no queda resuelta, como se compone -o se podría componer- el trayecto de la modernidad.

Esta tensa resistencia -más dinámica y cambiante que estática o estructural-, sobre la que la obra de arte se gana para sí, sumaría a la pregonada pureza del medio artístico la capacidad de permanecer en la «dureza» de no dejarse diluir por la intelección que la trae a significación (tanto de lo que significa como de lo que en ella, o por ella, se significa). O, formulándolo de otro modo, la soberanía por la que la obra moderna se gana para sí no puede desentenderse de la exigencia que le es principal: la de ser mirada. $Y$ esta exigencia -esta nueva tiranía- crece de forma proporcional al grado de soberanía -sea la de la forma en su autonomía, sea la de la imagen en su resistencia a la significación- que la obra alcanza. Hacia mitad del siglo XIX, con enclaves fundamentales en Ingres y Goya, la pintura debe pagar el precio de la libertad formal; y este precio, como digo, es el de no poder permitirse dejar de ser mirada. Antes de estas décadas románticas, y sobre todo post-románticas, la pintura sirvió a funciones simbólicas o de significación verbal, a los más altos poderes o a la reproducción de modelos existentes (que en ella quedaban representados y entendidos); esta "servidumbre» le concedía, no obstante, una densidad ontológica y hermenéutica que, llegados a Manet, será ya cosa del pasado.

Concentrando sus fuerzas en la nueva heteronomía de tener que ser mirada, la obra de arte despliega un mosaico de recursos para resultar "atractiva». Jonathan Crary se ha referido recientemente a este contexto en su espléndido libro sobre las Suspensiones de la percepción, donde se sirve de las nociones de atención y espectáculo para definir el espíritu de las últimas décadas del siglo XIX, pero lo que desearía sugerir aquí es que, a la vez que se asiste en esos años a la intensificación de la espectacularización (y cabría preguntarse si no estamos de este modo ante la «continuación» del paradigma estetizante-formalista surgido en el XVI/XVII), se hace posible hallar en la pintura del fin-de-siècle pistas hermenéuticas suficientes para integrar en la pregunta por la soberanía de la imagen moderna ciertos aspectos que no remitirían a la ontología espectacularista, sino a la potencia de extrañamiento que hace de la irreconocibilidad su agente de atracción más destacable.

Espectacularidad, por una parte, y, por otra, irreconocibilidad (sobre ella escribe Ortega unas líneas definitivas en La deshumanización del arte ${ }^{2}$ ) serían los recursos respectivos de dos vectores diferenciados de atracción de la mirada. Pero no sólo. Porque ambos dominios poieticos deben enfrentarse a la lógica de la significación. El espectáculo debe convertirse en visualidad inmediata y absoluta, apartando de sí cuanto pudiera haber de signo legible. De este modo, las poéticas formalistas de la Abstracción, tomadas en su radicalidad, exigirían, para su contemplación desinteresada, rigurosamente «visualista», la expulsión de los signos.

Sin embargo, habrán de ser las poéticas de la irreconocibilidad las que tensen su soberanía en una querella con los signos que no culmina en su supresión o expulsión, sino en su equivocación. O sea: no se trataría de evitar la presencia del signo, sino de provocar su parodia, su avería, su entorpecimiento, consiguiendo que sea la imagen la que domine al signo (convirtiéndose para ello en aparición y no en mera apariencia o copia), vengándose de él, invalidándolo, y, sobre todo, dejando en evidencia cuanto hay en él de cuerpo negado (desde el platonismo y el clasicismo: los dos grandes momentos de sometimiento de las imágenes a las Ideas). Dejemos esta querella sólo anunciada -a la espera de retomarla más abajo- y abundemos un poco más en la diferencia entre las formas puras y las imágenes irreductibles. Para ello, convendrá que reparemos en algunas declaraciones pertenecientes a la Crítica del juicio.

Es bien sabido con qué frecuencia recibe esta obra de Kant el honor de ser umbral de las estéticas formalistas, pero me parece que se atiende menos -si es que hay algo de Kant que se atienda menos, claro- a que en él se incuba también esta otra tradición a la que venimos refiriéndonos, la de la imagen resistiéndose. Junto a la actitud estética retenida en la contemplación de la representación, sólo interesada por las cualidades de las formas y no por sus significados o por su veracidad en términos de existencia empírica, hay en la tercera Crítica kantiana una concepción de la función 
imaginante -y por lo tanto una teoría de la imagen «creada»que no debemos pasar por alto en el intento de elaborar una hermenéutica de qué sea la imagen artística moderna. Porque si bien este libro de 1790 lleva a su culminación muchos de las asuntos nacidos en el transcurso de los siglos XVII y XVIII (la propia teoría del desinterés, que se retrotrae al platonismo de Shaftesbury; o cuanto, en términos generales, debe el concepto kantiano de belleza a la tradición artística neoclásica de la que es coetáneo), desde los que se erige el monumento a la representación pura que es la Crítica del juicio, me parece que puede hallarse también entre sus páginas una estética espectralista - de la imagen como aparición- que nos abre el paso al Romanticismo (y que aquí visitaremos guiados por las proclamas de Baudelaire sobre la imagen):

[... si en el juicio del gusto tiene que tomarse en consideración a la imaginación en su libertad, entonces ésta no es reproductiva, como sucede cuando está sometida a las leyes de la asociación, sino que tiene que tomarse como productiva y autosuficiente (como autora de formas libres de posibles intuiciones) (Kant, 2003: 194).

Y más abajo, en el epígrafe $§ 49$, dedicado a las capacidades del genio, se lee:

A partir de la materia que la naturaleza real le ofrece, la imaginación (en tanto que capacidad cognoscitiva productiva) es muy poderosa en la creación, por decirlo así, de otra naturaleza. [...] Aquí sentimos nuestra libertad frente a la ley de la asociación (que depende del uso empírico de aquella capacidad) según la cual tomamos prestada de la naturaleza la materia, pero donde podemos transformarla en algo totalmente diferente, a saber, en aquello que sobrepasa la naturaleza (Kant, 2003: 281).

La imaginación podrá ser, entonces, productora de lo nuevo (y no sin más, como todavía se sostiene en la Primera Crítica, sintética de lo aportado por la percepción): es un origen, un umbral de existencia nueva cuya naturaleza es la de ser imagen insólita o imprevista ${ }^{3}$. Imágenes que nacen de la libertad de una actividad dotada de suficiencia creadora para componer lo hasta entonces inexistente y, sobre todo, desconocido a la visión.
Es preciso que nos mantengamos en este mismo parágrafo («De las capacidades del ánimo que constituyen al genio») para encontrarnos con la noción kantiana de idea estética:

Por idea estética entiendo aquella representación de la imaginación que ofrece ocasión para pensar mucho, sin que, sin embargo, pueda serle adecuada ningún pensamiento determinado, esto es, un concepto; que, en consecuencia, ni alcanza ni puede hacer plenamente comprensible ningún lenguaje (Kant, 2003: 280-1)4.

La imagen que cumple la condición de ser «idea estética», la cual nos llevará a la caracterización de la imagen capaz de extrañarnos, tiene su fuerza en quedar por significar: en permanecer inaccesible al entendimiento. Sólo entonces se nos aparece la imagen en su presencia, cuando ésta se impone y no es habilitada para su uso como representación significante.

Hagamos abstracción de los casi setenta años que transcurren entre la publicación de la Crítica del juicio y el Salon de 1859 redactado por Baudelaire, más de medio siglo en el que la «facultad de Prometeo» ha disfrutado de una enorme consideración por parte de los poetas románticos ingleses, para encontrarnos con unas apreciaciones especialmente elocuentes acerca de la que recibirá los honores de ser «reina de las facultades». Baudelaire enfatiza esta expansividad de la imaginación impregnando con ella a las otras facultades: «Ella toca a todas las demás; las excita, las envía al combate. A veces parece que vaya a confundirse con ellas, y sin embargo permanece siempre siendo ella misma» (Baudelaire, 1968: 397) ${ }^{5}$.

Pero además le atribuye la capacidad de descomponer lo que recibe y de crear, mediante la disgregación de lo que se nos daba unido, un mundo nuevo: «Ella descompone toda la creación, y, con materiales amasados y dispuestos siguiendo reglas cuyo origen sólo está en lo más profundo del alma, crea un mundo nuevo [... ]» (Baudelaire, 1968: 397). Esta potencia de desobediencia respecto a las representaciones regladas por los criterios metafísicos o estéticos de orden, armonía, unidad, cuales son los sostenidas a lo largo del clasicismo y el neoclasicismo, requiere del artista que se dé a recomponer, de forma original y fuertemente subjetiva, un mundo inaugural; que se entregue a la tarea prometeica 
de alterar las significaciones conformadas en la estabilidad de lo dado como idéntico a sí mismo. En este punto, merece leerse lo que el propio Baudelaire nos presenta como «la fórmula principal» de la verdadera estética:

Todo el universo visible no es más que un almacén de imágenes y de signos a los que la imaginación dará un lugar y un valor relativo; es una especie de pasto que la imaginación debe digerir y transformar. Todas las facultades del alma humana quedar subordinadas a la imaginación, que las pone a todas a la vez bajo su dominio (Baudelaire, 1968: 399).

Corresponde a la libertad de la función imaginante disponer del orden recibido, jugando a los equívocos y las arbitrariedades, a las suspensiones de la verosimilitud y a las obstrucciones de la reconocibilidad. En rigor, podríamos suponer que esta superioridad de la imaginación conllevará el aniquilamiento definitivo de todo realismo "copista». La imaginación obtiene con todos los honores la potencia de insurgencia respecto a la ecuación que dota de mayor crédito ontológico a lo real percibido que a lo posible sugerido. Las imágenes gozarán al fin de la mayor libertad ${ }^{6}$. A cambio, deberán concentrar todas sus fuerzas en la seducción del espectador.

Pudiendo descomponer la identidad de lo recibido ya significado y dotada de las condiciones de crear lo otro, la imaginación se afirma como el medio prometeico con el que la obra de arte se resuelve ahora, en términos ontológicos, bajo la exigencia de producir imágenes y no sin más de reproducirlas; o sea: de crearlas y no sólo de recrearlas para la complacencia estética.

El tercer nombre en este trayecto por la soberanía de la imaginación es Lautréamont, de quien tomaremos un motivo suficientemente conocido: la mesa de disección en la que se produjo el encuentro de un paraguas y una máquina de coser. Vale la pena que acudamos al Canto VI de Los Cantos de Maldoror (1869), donde, en el contexto de definición de la belleza, nos topamos con una «imagen» cuya potencia de asombro es de difícil atenuación:

[...] si miráis hacia donde la calle Colbert confluye con la calle Vivienne, veréis, en la esquina formada por el cruce de ambas vías, a un personaje que muestra su silueta y dirige su ligera marcha hacia los bulevares. Pero acercándose más, cuidan- do de no atraer sobre uno mismo la atención del viandante, se advierte, con agradable asombro, ique es joven! Desde lejos, en efecto, se hubiera dicho que era un hombre maduro [...] Es bello como la retractilidad de las garras en las aves rapaces; o también como la incertidumbre de los movimientos musculares en las llagas de las partes blancas de la región cervical posterior; o mejor, como esa ratonera perpetua, constantemente tensada de nuevo por el animal atrapado, que puede cazar por sí sola, indefinidamente, roedores y funcionar incluso oculta bajo la paja; y, sobre todo, jcomo el encuentro fortuito de una máquina de coser y un paraguas en una mesa de disección! (Lautréamont, 1970: 200).

Más allá de la extravagancia que se figura en la reunión de una máquina de coser y un paraguas sobre una mesa de disección, quisiera reparar en el adjetivo empleado en la frase con la que esta imagen se nos da a ver: tal encuentro (la rencontre) es fortuito (fortuite). La palabra latina de procedencia es fortuitus («azoroso»), y con ella se significaría lo inesperado, lo que llega traído sin determinación causal identificable, de modo casual. Lo accidental de este encuentro no participa de la lógica de la verosimilitud: es ajeno a lo creíble. Es justamente esta indiferencia a las leyes ilusionísticas de la verosimilitud la que subyace en la atracción de los surrealistas por lo azaroso, en tanto que se abren en el acceso a lo insólito unas posibilidades cognoscitivas que de otro modo no nos serían propicias. Lo imprevisto es, para Breton y los suyos, un umbral privilegiado de revelaciones de gran valor transformador. El artista es el que ve en las imágenes "conocidas» lo todavía por significar (aquellos «nexos secretos», aquellas correspondances de Baudelaire que nos llevarán hasta el primer De Chirico).

Contra lo conocido y sus hábitos, la máquina de coser y el paraguas están ahí: se nos aparece la imagen que los acoge sobre la mesa, la imagen por la que se crea esta posibilidad (en rigor: imaginaria) indiferente a lo previsible. Esta imagen «surreal» posee la potencia de lo que permanece en las afueras de la significación: imágenes provocadoras de perplejidad, perturbadoras, capaces de desorientarnos en tanto que continúan aún por significar. Sólo entonces se nos muestra la imagen en su presencia: cuando se impone y no es reducida -apartada- a su uso como representación significante. Es entonces cuando la imagen se cumple como acontecimiento y aparición. 
Como vengo diciendo, la imagen (se) aparece al romperse el signo, y es por esto por lo que, desde Nietzsche a los surrealistas, el trabajo creador requiere de la tarea destructora. Lautréamont, provocando la imprevisión de las imágenes, y Nietzsche descubriéndonos en Verdad y mentira en sentido extramoral (escrito en 1873) que el lenguaje designativo no es más que construcción «humana» de signos, propician la apertura de nuevas posibilidades onto-cognoscitivas para lo que no es más, pero tampoco menos, que creación imaginaria, fundación de lo extraño, imagen ajena a las exigencias de lo real: indiferente a ellas y, por esto, dotada de potencia liberadora (de las tiranías de lo dado hacia la creación de posibilidades imprevistas). La imagen extrañante habrá de liberarnos a condición de alterarnos, de tomarnos, ella absoluta, en la participación -y no en la contemplación teorética, estética- salvadora de lo desconocido.

De las evidencias de la significación «saltamos» -más que transitamos- a las apariciones de las imágenes mostrándose a sí mismas. Desde las homotopías de la identificación, caemos en las alteraciones de la identidad y las estrategias de obstrucción de los signos. La mesa imaginada por Lautréamont es, con prioridad sobre la concitación de objetos heteróclitos que en ella «acontece», máquina creadora de extrañamientos.

Llegados aquí, creo que podríamos afirmar que este vector de la imagen soberana, el que se enfrenta al signo minándolo de equivocidad, el que avanza confundiéndonos, tiene en la formulación de la imagen-fantasma, o simulativa, tal y como se presenta en el Sofista y a la que el propio Deleuze se ha referido de manera fundamental, su definición hermenéutica más completa. Detengámonos en extraer de las páginas de Deleuze cuanto pudiera alumbrarnos en lo relativo a la naturaleza de la soberanía de la imagen y la índole simulativa y usurpatoria de lo real que parece serle propia.

Deleuze se pregunta, a la manera de Nietzsche, por la inversión del platonismo restituyendo cierta escisión originaria, determinante para el porvenir occidental de las imágenes, fijada en el Sofista (235 d) entre las imágenes producidas por la técnica figurativa (tékhnē eikastiké), esto es, copias sin otro cometido que el de reproducir sus modelos con obediente e inequívoca fidelidad, y aquellas otras, las imágenes-simulaciones, que «sólo aparentan parecerse» (236 b); entre las imágenes que se cumplen prestándose a que por ellas se alcance el modelo, y las apariencias afa- nadas en quedar ellas mismas «por delante», imponiéndose como presencias engañosas.

Sin embargo, desde el momento mismo en el que se acomete esta diferenciación inicial ambos términos se vuelven confusos, borrosos, indefinidos, y la razón de esta frustración de la mencionada división, por la que se quiso proteger a la imagen-copia separándola del falso pretendiente que es la imagen-fantasma, radica en que el simulacro no tiene más identidad que la de ser potencia capaz de producir equívocos e ilusiones. Su poder mayor radica en su capacidad de invalidación del vínculo, respetuoso de lo real, entre el modelo y la copia. La imagen-simulación «no es simplemente una falsa copia, sino que pone en cuestión las nociones mismas de copia... y de modelo» (Deleuze, 1969: 295).

Ante la amenaza de que la «legítima» relación de subordinación de la reproducción al modelo o al original, cuyas existencias pueden verificarse, sufriese el sabotaje del simulacro, el cual sabe aparentar parecerse a lo que sin embargo no existe, Deleuze nos descubre la intención de Platón: «Se trata de asegurar el triunfo de las copias sobre los simulacros, de refouler [inhibir, reprimir] los simulacros, de mantenerlos encadenados al fondo, impidiéndoles salir a la superficie e insinuarse por todas partes» (Deleuze, 1969: 296). En este mismo sentido, pueden leerse estas otras palabras pertenecientes a Différence et répétition (1968):

Todo el platonismo está construido sobre esta voluntad de cazar los fantasmas o simulacros [...] Es por esto por lo que nos parece que, con Platón, se toma una decisión filosófica de la mayor importancia: la de subordinar la diferencia a los poderes de lo Mismo y la Semejanza supuestos como iniciales, la de declarar la diferencia impensable en ella misma, y enviarla, a ella y a los simulacros, al océano sin fondo (Deleuze, 1968: 165).

Quedémonos, de la lectura de estas líneas, con las referencias que en ellas se hacen al lugar o posición al que los simulacros son condenados: "encadenados al fondo", "al océano sin fondo»; y retengamos para nuestro propósito una simple consideración: la inversión del platonismo habría de consistir en la emergencia de los fantasmas conquistando para sí el espacio imaginario de la superficie insondable.

Es justamente esto, mostrar, hacer aparecer, imponer la presencia, cuanto se lleva a cabo en el arte moderno, de- 
dicado de este modo a desarrollar operaciones de emergencia de los simulacros liberándolos de las ideas, de la exigencia de responder a la verdad y, con ellas, del vínculo de validez cognoscitiva entre el original y la copia, el modelo y su reproducción?

«Se define la modernidad por la potencia del simulacro", escribe Deleuze (1969: 306). El ensayo de interpretación que aquí compartimos toma la forma concisa de esta pregunta: ¿Cómo «se implica» la historia del arte moderno en la historia moderna del simulacro? Y, según lo entiendo, cabría responder que la implicación es radical, hasta el punto de que los dominios de saber y cultura que designamos como «arte moderno» son constituidos -o configurados...- por la insurgencia de los simulacros. El arte moderno transcurre en tal caso como destino en el que la imagen-fantasma venga la inhibición a la que fue sometida por las exigencias de verdad impuestas por el platonismo y el clasicismo. El arte moderno transcurre en el conocimiento de «esta técnica que no produce imágenes, sino apariencias»; su saber es el de la técnica simulativa (tékhné phantastiké).

En este sentido, cabría referir a ciertas prácticas artísticas del siglo XIX -cierto Goya, cierto Manet, Cézanne, Odilon Redon- las palabras que Ortega dirige, en La deshumanización del arte, a la pintura de su época:

Lejos de ir el pintor más o menos torpemente hacia la realidad, se ve que ha ido contra ella [...] Con las cosas representadas en el cuadro nuevo es imposible la convivencia: al extirparles su aspecto de realidad vivida, el pintor ha cortado el puente y quemado las naves que podían transportarnos a nuestro mundo habitual. Nos deja encerrados en un universo abstruso, nos fuerza a tratar con objetos con los que no cabe tratar humanamente (Ortega y Gasset, 1987: 27).

Donde creíamos encontrar, en el signo, transparencia y transitividad, además de un funcionamiento impecable -o sea, imperceptible- y la voluntad afanosa de negar su propia contingencia, de imponer alguna univocidad, arbitraria pero sosegadora a fuerza de repeticiones, nos topamos abruptamente con desarreglos, con desajustes, ante presencias en inmanencia donde quisimos que hubiera puzles ilusionándonos con algún sentido bien fijado: estable y estático. Habitable por el entendimiento y sus órdenes.
En su libro sobre Francis Bacon, donde usa la categoría hermenéutica de lo figural formulada por Lyotard, Deleuze, refiriéndose a los modos característicos de la pintura del dublinés, aprecia muy bien esta doble vía de resistencia a la figuración que nos viene ocupando:

No solamente el cuadro es una realidad aislada (un hecho), no solamente el tríptico tiene tres paneles aislados que ante todo no se deben reunir en un mismo marco, sino que la propia Figura está aislada en el cuadro, por el redondel o por el paralepípedo. ¿Por qué? Bacon lo dice a menudo: para conjurar el carácter figurativo, ilustrativo, narrativo, que la Figura tendría necesariamente si no estuviera aislada. La pintura no tiene ni modelo que representar, ni historia que contar. A partir de ahí ella tiene dos vías posibles para escapar de lo figurativo: hacia la forma pura, por abstracción; o bien hacia lo puramente figural, por extracción o aislamiento. Si el pintor tiende a la Figura, si toma la segunda vía, será, pues, para oponer lo figural a lo figurativo (Deleuze, 1996: 9) ${ }^{8}$.

Es preciso que dediquemos el último tramo de estas páginas a la naturaleza usurpatoria y falsificante de la imagen-fantasma, comprendiendo que esta voluntad suplantadora de lo real forma parte de la identidad del arte moderno. La imagen simulativa des-realiza lo tenido por «mundo real» y produce efectos ilusionísticos contra todo fundamento metafísico, causal o sustancial:

La copia es una copia dotada de semejanza, el simulacro es una imagen sin semejanza [...] puede, sin duda, incluso producir un efecto de semejanza, pero es un efecto de conjunto [effet d'ensemble: efecto de impresión general], todo exterior, y producido por medios totalmente diferentes de aquellos que trabajan en el modelo (Deleuze, 1969: 297).

Minando de contingencia y equívocos el orden aplicado a lo real, irrealizándolo, las imágenes falseadoras -apariciones haciéndose pasar por copias autorizantes de la mismidad- despliegan para ello estrategias de desestabilización del sujeto respecto a las distancias protectoras obtenidas por el entendimiento y la actitud estética al convertir el mundo en su representación.

Sobre esta pragmática de usurpación por la que el simulacro se hace con el destino del arte moderno, ha escrito 
con inesperada contundencia Ortega y Gasset en su «Ensayo de estética a manera de prólogo», de 1914:

El arte es esencialmente IRREALIZACIÓN. Podrá, dentro del ámbito estético, haber ocasión para clasificar las tendencias diversas en idealistas y realistas, pero siempre sobre el supuesto ineludible de que es la esencia del arte creación de una nueva objetividad nacida del previo rompimiento y aniquilación de los objetos reales. Por consiguiente, es el arte doblemente irreal: primero, porque no es real, porque es otra cosa distinta de lo real; segundo, porque esa cosa distinta y nueva que es el objeto estético lleva dentro de sí como uno de sus elementos la trituración de la realidad (Ortega, 1987: 171).

Cuando hay arte «moderno», desde cuando lo hay, lo real debe ser atacado -ha debido serlo- por la fuerza de las formas. Por la imposición de las imágenes. Quizá pudiéramos decirlo mediante una fórmula algo simplificadora: el arte se realiza a la vez que anula lo real. De este modo, el sentido contenido hacia el final de las líneas citadas obtendría su mayor evidencia: lo que el arte busca -circunscribiéndolo por mi parte a su historia desde la época renacentista y de forma particular al dominio de las imágenes- es erigirse en su irrealismo; esto es, en la desautorización de lo recibido y tenido por real. Es la «actitud» de desobediencia, necesaria para cualquier conquista de soberanía, lo que Platón condena en el fantasma: la posibilidad misma de que cuente con la sabiduría de fascinarnos sin prestarse a las exigencias «realistas» (siendo el realismo una ideología de creencia en lo dado por real). Sin ceder sus fuerzas ilusionísticas, como sí hace la imagen-copia, al arraigo de la verdad (la identidad sin alteridad, las ideas sin los fantasmas...).

Tomando la afirmación de Ortega como señuelo, valdría la pena darnos a la tarea de reunir las «pruebas» de esta propensión denegadora intrínseca a la creación artística en el transcurso de la modernidad. Propensión que se elaborará de forma creciente y con especial énfasis entre las artes de la visión, las que se sirven -utilizando la precisión de Lessing- de "signos naturales» y a las que debemos toda una constelación de ingenierías dirigidas a la usurpación irrealizante; desde el sistema renacentista de la perspectiva hasta las diversas virtualidades digitales. Mediante la acción de muy diversos procedimientos de desrealización, «las artes de la imagen» han conquistado su soberanía sosteniéndose en la tensión de un duelo con los «objetos reales»; haciendo de esta confrontación inconclusa la condición principal de su trayecto de afirmación.

Entre la copia y el fantasma, entre el trampantojo y la fotografía, entre los inicios del género de naturalezas muertas y las pinturas de Tom Wesselmann o las fotografias de maquetas-simulaciones de Thomas Demand, entre las escenificaciones de Tintoretto, los tableaux vivants del XVIII y las escenas compuestas por Jeff Walls, la vocación de irrealización se ha mantenido como una constante inherente al itinerario de las artes visuales. Cabría decir que el destino de la imagen es, por encima de otros, el de relegar lo real para ella anteponerse a la visión. Lévinas nos da a este respecto unas palabras fundamentales:

La función elemental del arte, que se reconoce en sus manifestaciones primitivas, consiste en proporcionar una imagen del objeto en lugar del objeto mismo [...] Esa manera de interponer entre nosotros y la cosa una imagen de la cosa tiene como efecto separar la cosa de la perspectiva del mundo (Lévinas, 2000: 69) 9 .

Liberado de sus significaciones y servidumbres habituales, el objeto recibe los honores estetizantes de ser convertido en imagen. Para que se produzca esta conversión, radical, de mutación de la cosa en su imagen, no basta «mirar», sino que se requiere saber apartar el mundo, saber eliminar el mundo que sobra a las imágenes. Quedándonos sin mundo con el que de ellas defendernos.

\section{Notas}

1 Está en el propósito de la "propuesta hermenéutica» que se presenta en estas páginas liberar a las figuras de la tiranía "abstraccionista» de las formas (o, más precisamente, las Formas). Ya Erich Auerbach se detuvo, en su libro clásico sobre la significación de la noción de figura, en las diferencias existentes entre ambos campos semánticos: «En el ámbito del uso platónico-aristotélico del idioma, la formación filosófica y retórica había asignado a cada una de estas

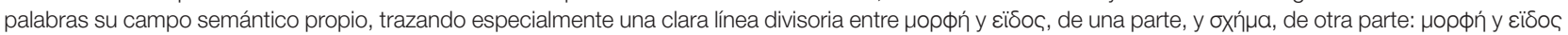


son la 'forma' o la 'idea' que constituyen o informan la materia, mientras que oxńua es la 'configuración' puramente sensorial de dicha forma [...] Se imponía

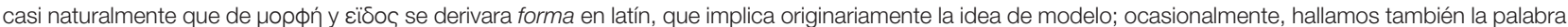
exemplar; por el contrario, a oxńua corresponde casi siempre figura en latín" (Auerbach, 1998: 47-8). La forma es molde y modelo; la figura es imagen plástica.

2 Como es sabido, es este factor de irreconocibilidad el que dota al arte moderno de su capacidad de «deshumanización»: «[...] el arte de que hablamos no es sólo inhumano por no contener cosas humanas, sino que consiste activamente en esa operación de deshumanizar [...] No se trata de pintar algo que no sea por completo distinto de un hombre, o casa, o montaña, sino de pintar un hombre que se parezca lo menos posible a un hombre, una casa que conserve de tal lo estrictamente necesario para que asistamos a su metamorfosis, un cono que ha salido milagrosamente de lo que era antes una montaña, como la serpiente sale de su camisa" (Ortega y Gasset, 1987: 28).

3 En el § 28 de su Antropología en sentido pragmático, se lee sobre lo mismo: «La imaginación (facultas imaginandis) o facultad de tener intuiciones sin la presencia del objeto, es ya productiva, esto es, una facultad de representarse originariamente el objeto (exhibitio originaria), que antecede, por tanto, a la experiencia; o bien reproductiva, es decir, una facultad de representación derivada (exhibitio derivativa) que devuelve al espíritu una intuición empírica que habíamos tenido antes» (Kant, 2004: 76-7).

4 Y más abajo: «En una palabra, la idea estética es una representación de la imaginación agregada a un concepto dado, que está ligada con una tal multiplicidad de las representaciones parciales en el uso libre de la misma, que no cabe encontrar para ella ninguna expresión que designe un concepto determinado; es, pues, una representación que permite añadir mentalmente a un concepto muchas cosas inefables, cuyo sentimiento vivifica las capacidades cognoscitivas y enlaza al espíritu con el lenguaje en tanto que mera letra" (Kant, 2003: 284).

5 En el contexto de sus escritos sobre Poe, había declarado: «La imaginación es una facultad casi divina que ante todo percibe, fuera de los métodos filosóficos, las relaciones íntimas entre las cosas, las correspondencias y las analogías» (Baudelaire, 1968: 350).

6 Clément Rosset define la imaginación en clave moderna dotándola del factor de sugerencia, diferenciándola de la imaginación servil de la percepción y auxiliar de la memoria a la que otorga la capacidad de evocación: «Tal es esencialmente la concepción de la imaginación que se puede llamar clásica: la imaginación es una sensación no únicamente disminuida (como lo muestran todos los análisis de la imaginación que oponen la palidez de la copia a los vivos colores del original), sino sobre todo una sensación constreñida [...]. Si al contrario se considera la imaginación como un poder de sugestión de imágenes libres y emancipadas respecto a lo real, extrañas al lote de imágenes ofrecidas a la percepción ordinaria, la función de la imaginación no consistiría ya en evocar las percepciones, sino más bien en distraerse en la producción de 'representaciones' tan preciosas como que ellas no representan nada de lo ya conocido, es decir, no representan nada" (Rosset, 2006: 94-5).

7 Vale la pena ir a las propias líneas de Deleuze: «Invertir el platonismo significa por tanto: hacer subir los simulacros, afirmar sus derechos entre los iconos y las copias [...] El simulacro no es una copia degradada, posee una potencia positiva que niega el original y la copia, el modelo y la reproducción» (Deleuze, 1969: 302).

8 Algo más abajo, vuelve Deleuze a este mismo asunto : «Hay dos maneras de sobrepasar [dépasser] la figuración (es decir, a la vez lo ilustrativo y lo narrativo): o bien hacia la forma abstracta o bien hacia la Figura. A esta vía de la Figura Cézanne le da un nombre sencillo: la sensación» (1996: 27).

9 En su escrito sobre «La realidad y su sombra» (1948), se lee a este respecto: «El procedimiento más elemental del arte consiste en sustituir un objeto por su imagen. Imagen y no concepto" (Lévinas, 2001: 47).

\section{Bibliografía}

AUERBACH, Erich (1998), Figura, Trotta, Madrid.

BAUDELAIRE, Charles (1968), CEuvres complètes, Éditions du Seuil, París.

CRARY Jonathan (2008), Suspensiones de la percepción. Atención, espectáculo y cultura moderna, Akal, Madrid.

DELEUZE, Gilles (1968), Différence et répétition, P.U.F., París.

- (1969), Logique du sens, Éditions de Minuit, París.

- (1996), Francis Bacon. Logique de la sensation, Éditions de La Différence, París.

GREENBERG, Clement (2006), La pintura moderna y otros escritos, Siruela, Madrid.

KANT, Immanuel (2003), Crítica del discernimiento, Antonio Machado Libros, Madrid.

- (2004), Antropología en sentido pragmático, Alianza Editorial, Madrid.

LAUTRÉAMONT (1970), Les Chants de Maldoror, Bordas, París.

LÉVINAS, Emmanuel (2000), De la existencia al existente, Arena Libros, Madrid.

- (2001), La realidad y su sombra. Libertad y mandato. Trascendencia y altura, Trotta, Madrid.

ORTEGA Y GASSET, José (1987), La deshumanización del arte y otros ensayos de estética, Alianza Editorial, Madrid.

ROSSET, Clément (2006), Fantasmagories suivi de Le réel, l'imaginaire et l'illusoire, Éditions de Minuit, París. 
